\title{
A Farmer's Account: Case Study on the Effect of Rainfall and Temperature to Grain Cultivation in Southwestern Saskatchewan, Canada
}

\author{
Tyler Pittman ${ }^{1}$, Rory Pittman ${ }^{2} \&$ Jeremy Pittman ${ }^{3}$ \\ ${ }^{1}$ Biostatistics Department, Princess Margaret Cancer Centre, Toronto, Canada \\ ${ }^{2}$ Department of Earth and Space Science and Engineering, York University, Toronto, Canada \\ ${ }^{3}$ School of Planning, University of Waterloo, Waterloo, Canada \\ Correspondence: Tyler Pittman, Biostatistics Department, Princess Margaret Cancer Centre, Toronto, ON., M5G \\ 2M9, Canada. Tel: 1-416-946-4501 ext. 4054. E-mail: pittman.tyler@gmail.com
}

Received: March 17, 2020

Accepted: April 27, $2020 \quad$ Online Published: May 15, 2020

doi:10.5539/jas.v12n6p1

URL: https://doi.org/10.5539/jas.v12n6p1

\begin{abstract}
The production of cereal, legume and oilseed crops on the prairie region of Canada is largely rainfed, with high variability in the accumulation and timing of precipitation. In turn, the fluctuation of climate imparts change in farming practice. The objective of the current study is to measure the effect of rainfall and temperature on grain yield, based on longitudinal data for multiple crops on a Saskatchewan farming operation. Adjustment was made for days to maturity, fertilizer management, crop inputs, and procedures (e.g., harvest method). Detailed and thorough records of rainfall and farming routine were obtained from a farm operator on different field plots over 33 consecutive growing seasons from 1986 to 2018. The efficacy of multiple adaptive farming practices to crop yield were also evaluated, and included seed treatment, swathing, desiccation, and in-crop spraying of fungicide or pesticide. Statistical models were formulated for the association of these factors to crop yield for canaryseed (Phalaris canariensis L.), canola (Brassica napus L.), lentil (Lens culinaris Medik.) and wheat (Triticum turgidum L.). Results from this study show that temperature and rainfall above the long-term average were negatively associated with wheat yield, although the effect modification between average temperature and cumulative rainfall was positively associated with wheat yield. Over $63 \%$ of the observed variation in crop yield was attributable to planting year on this farming operation. Crop diversification is key to mitigate the effects of extreme rainfall and temperature variation on yield in this agroregion.
\end{abstract}

Keywords: crop yield, dryland agriculture, crop inputs, longitudinal study, field records

\section{Introduction}

Dryland farming with inorganic fertilizer management and other inputs is the basis of conventional agriculture on the northern Great Plains of Canada and the United States (Grant \& Flaten, 2019). Variability in rainfall has long been a challenge to dryland agriculture in this region (Hopkins, 1935). Improvement in farming practice among producers has come from the result of persistent adaptation yielded from scientific discovery (Lafond, 1994). However, findings from small plot field experiments may not be observed to have the same effect among producers due to uncontrolled events (Fernandez, Turkington, \& May, 2009). Random occurrences such as precipitation events affect soil moisture, which in turn influences when field activities can be undertaken for an area spanning many hectares. In particular, seeding, crop spraying and harvest activities are often delayed due to excess soil moisture (Perilli, Mitchell, Grant, \& Pisante, 2010). On the Canadian prairie, large amounts of variation in crop yield have been attributed to seeding rate, fertilizer use and days to maturity (May et al., 2012).

Adaptation to environmental and climate challenges is important for sustainable agriculture and is reflected in the development of crop cultivars (McCallum \& DePauw, 2008). Over the past three decades on the Canadian Prairies, the use of chemical seed treatment (Grant, Bailey, Harapiak, \& Flore, 2002), herbicides (McCallum \& DePauw, 2008), fungicides (Cruz et al., 2012), pesticides (Gossen, Peng, Wolf, \& Mcdonald, 2008), and the desiccation of crops at maturity (Zhang, Johnson, Mueller, \& Willenborg, 2017) have become common suffusion practices for obtaining superior crop yield and quality. No-till farming and crop rotations with the inclusion of canola and pulse cultivars have been implemented in lieu of a wheat and summerfallow sequence (Gan, Miller, 
Mcconkey, \& Zentner, 2003; McCallum \& DePauw, 2008). However, there are questions about the efficacy (Gossen et al., 2008) and environmental sustainability of modern farming methods that involve the use of pesticide products (Waite, Cessna, Grover, Kerr, \& Snihura, 2004). Many research attempts on the usage of pesticide products by producer with regard to conventional practice suffer from an absence of records that contain detailed information for exposure history (Johnson et al., 1993).

The objective of the present study is to examine the longitudinal association between average temperature and cumulative rainfall over the growing season to yield for different crops, after controlling for crop inputs and farming practices (e.g., crop spraying events). Information is obtained from detailed field records as documented by a farm operator over three decades. It is hypothesized that, (i) there is a response to grain yield from average temperature and rainfall and (ii) some farming practices are unassociated with grain yield, or could be in fact be detrimental.

\section{Materials and Methods}

\subsection{Area Description}

The site of this observational study is a farming operation in Saskatchewan, Canada located 60 km northwest of Swift Current. The climate of the study site is classified as semi-arid (Gan et al., 2003). Summary information of precipitation and temperature by month is given in Figure 1. Aggregate rainfall (excluding other forms of precipitation) over particular years was extremely variable. A minimum of $100 \mathrm{~mm}$ (year 2003) and a maximum of $515 \mathrm{~mm}$ (year 2016) were recorded. Examining July, the mean temperature varied from a minimum of $15.1^{\circ} \mathrm{C}$ in 1993 to a maximum of $22.6^{\circ} \mathrm{C}$ in 2007 . In the course of the growing seasons, extremes in temperature ranged from a low of $-10.0{ }^{\circ} \mathrm{C}$ (year 1996) to a high of $39.8^{\circ} \mathrm{C}$ (year 2018). 


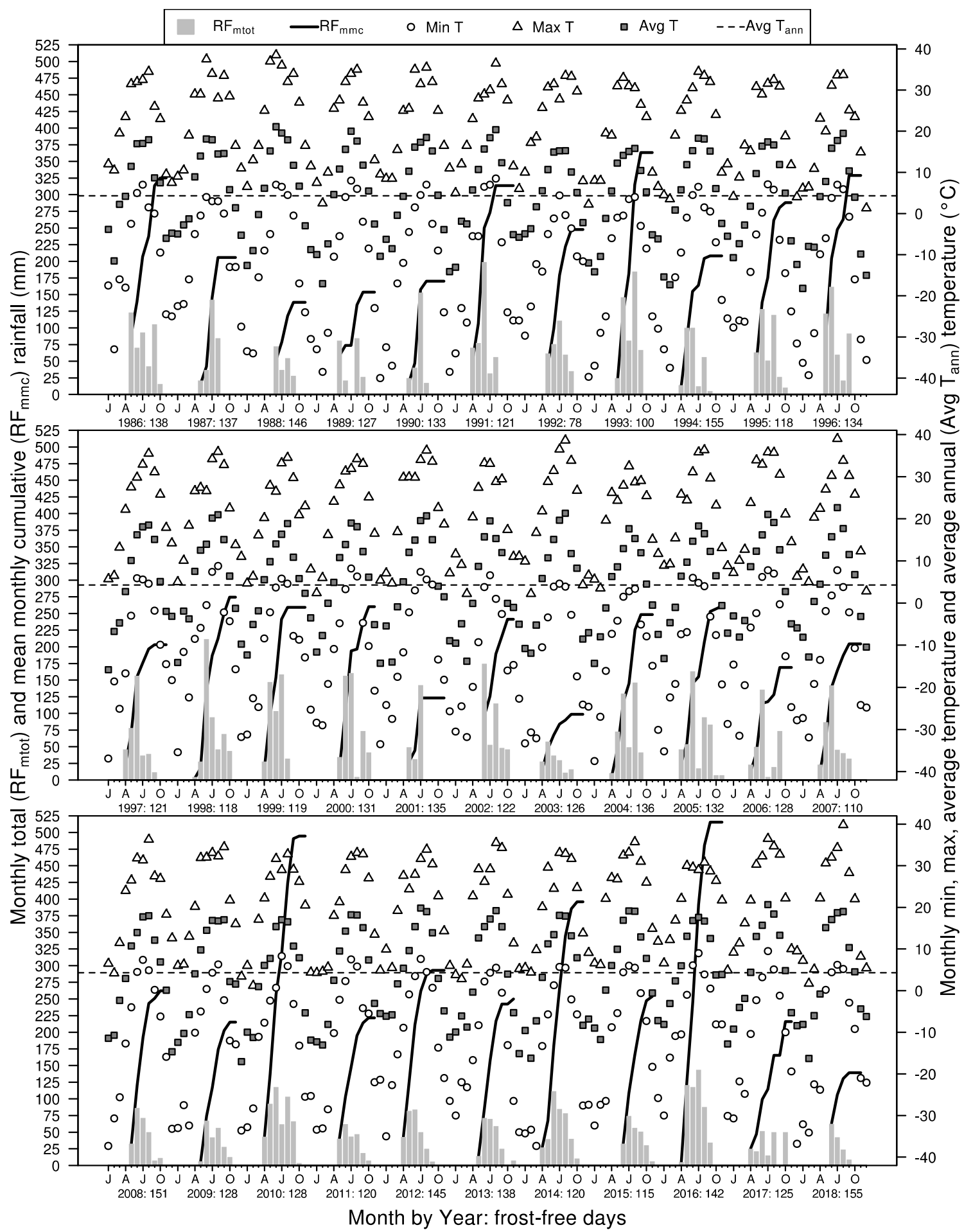

Figure 1. Mean monthly cumulative and total rainfall recorded at the farm site; monthly maximum, minimum and average temperature at Swift Current, Saskatchewan from 1986 to 2018. WMOs ID: 71146 (1986-1991), 71870 (1992), 71146 (1993-2011), and 71142 (2012-2018)

The area of the farming operation changed over the study period, expanding from 8 disjoined fields with approximately 256 cultivated hectares in 1986, to 38 disjoined fields with 1276 cultivated hectares in 2018 (Figure 2). Mean elevation of the cultivated fields was approximately $650 \mathrm{~m}$ above sea level. Vertisolic soils are predominant for the entire farming site (Anderson, 2010). 

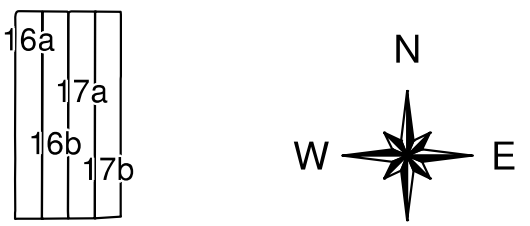

S
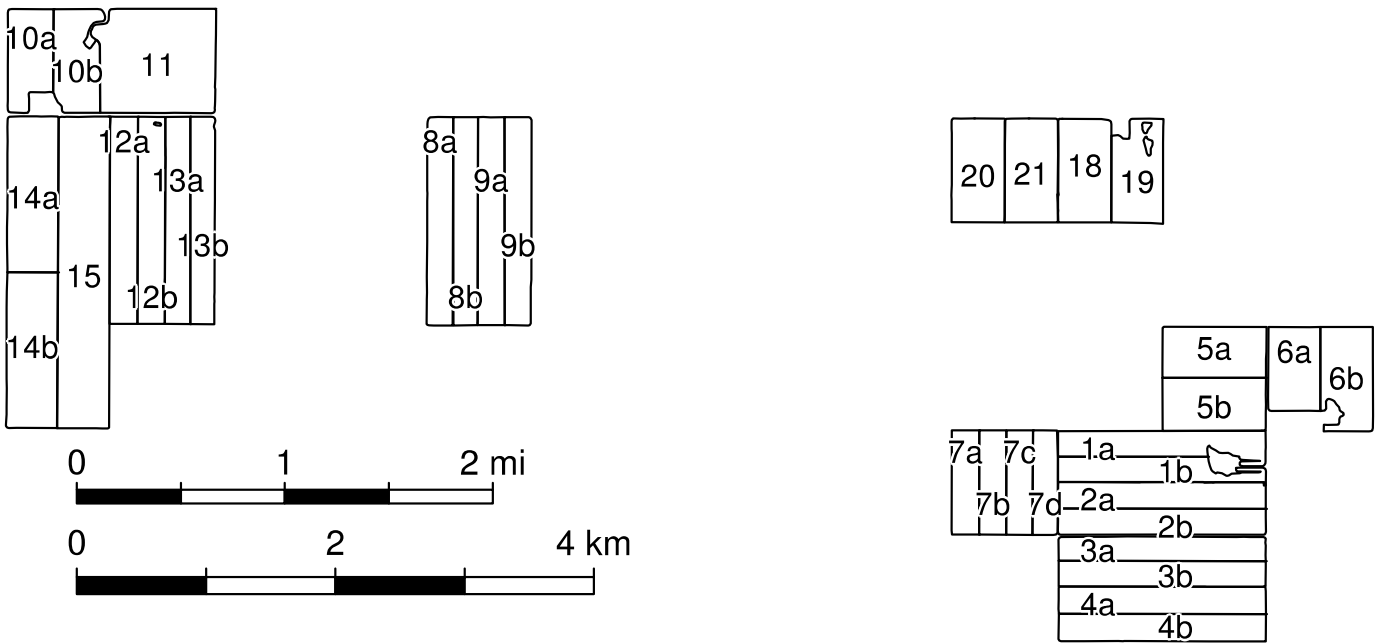

Figure 2. Field boundaries of the farming operation

\subsection{Historical Rainfall and Crop Production Data}

Daily accumulation of rainfall between 1986 and 2018 was recorded at a dwelling within $4 \mathrm{~km}$ to the centroid of the farming operation. Moisture was collected in a graduated cylinder rain gauge, which was placed in an open area in the center of the farmyard site (i.e., away from trees and buildings). Historic temperature data was accessed from 4 weather stations in Swift Current (WMOs ID: 71146 (1986-1991), 71870 (1992), 71146 (1993-2011), 71142 (2012-2018)) over the 33-year period (Environment Canada, 2019). Swift Current is one of the closest government-run weather stations to the farming operation, and it has one of the best records for the focal region.

The farm was strictly rainfed. Wheat (Triticum turgidum L.) and lentils (Lens culinaris Medik.) were the two dominant crops. Secondary crops planted through rotation included: canola (Brassica napus L.), canaryseed (Phalaris canariensis L.), chickpea (Cicer arietinum L.), field pea (Pisum sativum L.) and spring barley (Hordeum vulgare L.). Commercially-obtained fertilizers consisted of nitrogen (N), phosphorus (P), potassium chloride $(\mathrm{KCl})$ and sulphur $(\mathrm{S})$. Fertilizers were not applied in the same proportions for all crops. Foliar application of copper sulphate was practiced infrequently for wheat crops.

Detailed records of each field activity were documented by the farm operator, with application amount and date. Crop spraying with registered herbicides were utilized in this farming operation, as was spray application of fungicide and pesticides (less frequently). Even coverage at a recommended rate for the entire field was practiced in crop spraying. Seed treatment with registered products was utilized prior to planting for either the whole field or was not utilized at all. A list of crop cultivars grown is presented in Table 1. 
Table 1. Crop cultivars grown at the farming operation from 1986 to 2018

\begin{tabular}{lllllll}
\hline \multicolumn{7}{c}{ Cultivar grown, listed by first use } \\
\hline Barley & Canaryseed & Canola & Chickpea & Field Pea & Lentil & Wheat \\
\hline Harrington & Keet & 5440 & Sanford & CDC Golden & Laird & Wascana \\
CDC Copeland & CDC Togo & L156H & Myles & & Richlea & Columbus \\
& CDC Calvi & L252 & CDC Yuma & & CDC Grandora & Kyle \\
& L140P & CDC Xena & CDC Plato & Laura \\
& L233P & & CDC Greenland AC Avonlea & AC Strongfield \\
& & & & CDC Viceroy & AC Arigator \\
& & & & CDC Greenstar & AC Navide \\
& & & & & AC Brigade \\
\hline
\end{tabular}

\subsection{Determination of Rainfall and Temperature Features}

Cumulative rainfall over the growing season as observed at the centralized dwelling site of the farming operation was derived for each field by planting year. Days to maturity, denoting the growing season, was determined as the interval between seeding date to swathing or desiccation date (if applicable), or days between planting and straight combining. Average temperature, minimum temperature and maximum temperature were also obtained for each field from planting date to harvest date from linkage to data reported from the weather stations in Swift Current. Occurrences of drought, overland flooding and hail were recorded for each field by the farm operator.

\subsection{Statistical Modeling}

Statistical models with fixed and random effects were formulated for each crop with more than 40 field observations (canaryseed, canola, lentil and wheat). Bayesian inference with Markov chain Monte Carlo (MCMC) methods was utilized with the MCMCglmm package (Hadfield, 2010) in R version 3.5.1 (R Core Team, 2018). An effective sample size of 2,000 per parameter was desired in the posterior distribution. This was achieved with $13,888,889$ iterations, using a $10 \%$ burn-in and a thinning factor of 6,250 to diminish autocorrelation. For the fixed effects, proper diffuse priors with a Gaussian distribution $\left(\mu=0, \sigma^{2}=10^{10}\right)$ were specified (McDonald, Stott, Townley, Hodgson, \& Griffith, 2016). Priors with an inverse Wishart distribution (V $=1, v=1$, alpha- $\mu=0$, alpha- $\mathrm{V}=0)$ were specified for the random effects, and $(\mathrm{V}=1$ and $v=0)$ for the residuals. Autocorrelation was less than 0.1 in the Markov chains for all models.

Dry yield (in $\mathrm{kg} \mathrm{h}^{-1}$ ) was the response variable for each statistical model. Fixed effects comprised of explanatory variables that could be modified easily during the growing season, as well as climatic variables. These included rates (in $\mathrm{kg} \mathrm{h}^{-1}$ ) of: inoculant, nitrogen, potassium chloride, phosphorus, seed and sulphur; type of inoculant used, harvest method, and application of foliar copper sulphate, fungicide, pesticide (through in-crop spraying), and seed treatment. Days to crop maturity, average temperature and rainfall accumulation between dates of i) seeding and ii) swathing/desiccation or straight combining were derived from linkage of the field records to rainfall and temperature datasets. These climatic variables were also modeled as explanatory variables. Fixed effect variables with fewer than 5 observations for category counts (i.e., drought, flood, hail) were excluded from analysis in the random intercept models.

Random effect variables consisted of: crop cultivar, field, planting year and crop planted in the previous year. All four random effect variables were included in the random intercept models for canaryseed, lentil and wheat crop types; for canola no random effects were modeled due to small sample size. The deviance information criterion (DIC) was utilized to evaluate model fit through the covariance structure arising from priors. Statistical significance was assessed at MCMC P-value $<0.05$.

\section{Results}

\subsection{Seeding Rate and Fertilizer Inputs}

Table 2 presents the mean application rates of fertilizer nutrients and seed at sowing for: barley, canaryseed, canola, chickpea, field pea, lentil and wheat crops during the 33-years of study. Among wheat crops, the mean seeding rate was $83.1 \mathrm{~kg} \mathrm{ha}^{-1}$ with: $51.6 \mathrm{~kg} \mathrm{ha}^{-1}$ of nitrogen, $22.1 \mathrm{~kg} \mathrm{ha}^{-1}$ of phosphorus, $2.1 \mathrm{~kg} \mathrm{ha}^{-1}$ of potassium chloride and $7.6 \mathrm{~kg} \mathrm{ha}^{-1}$ of sulphur applied. The lowest seeding rate (mean $5.2 \mathrm{~kg} \mathrm{ha}^{-1}$ ) was observed among canola crops; however, canola generally had the most fertilizer applied. Regarding nitrogen, field pea crops had the least mean fertilizer application at $5.6 \mathrm{~kg} \mathrm{ha}^{-1}$, while mean fertilizer application was highest with canola at $94.0 \mathrm{~kg} \mathrm{ha}^{-1}$. Potassium chloride fertilizer was never utilized when planting canola, chickpeas or field peas. Barley crops had the highest potassium chloride application on average, at $8.1 \mathrm{~kg} \mathrm{ha}^{-1}$. Granular or peat type 
inoculant was applied at seeding in all chickpea and field pea crops. The majority of lentil crops were grown with granular or peat type inoculant, with liquid type inoculant being utilized for the remainder.

Table 2. Summary of crop input and climate characteristics at the farming operation from 1986 to 2018

\begin{tabular}{|c|c|c|c|c|c|c|c|}
\hline & \multicolumn{7}{|c|}{ Crop yield and inputs, climate characteristics and random effects for fields [n] planted } \\
\hline & $\begin{array}{l}\text { Barley } \\
{[\mathrm{n}=5]}\end{array}$ & $\begin{array}{l}\text { Canaryseed } \\
{[\mathrm{n}=82]}\end{array}$ & $\begin{array}{l}\text { Canola } \\
{[n=42]}\end{array}$ & $\begin{array}{l}\text { Chickpea } \\
{[\mathrm{n}=11]}\end{array}$ & $\begin{array}{l}\text { Field Pea } \\
{[n=6]}\end{array}$ & $\begin{array}{l}\text { Lentil } \\
{[n=187]}\end{array}$ & $\begin{array}{l}\text { Wheat } \\
{[n=290]}\end{array}$ \\
\hline \multicolumn{8}{|l|}{ Fixed Effects } \\
\hline \multicolumn{8}{|l|}{ Mean (SD) or Frequency } \\
\hline Yield $\left[\mathrm{kg} \mathrm{ha}^{-1}\right]$ & $3260(1000)$ & $1290(400)$ & $2460(490)$ & $1170(560)$ & $2410(230)$ & $1650(580)$ & $2940(1020)$ \\
\hline Seed Rate $\left[\mathrm{kg} \mathrm{ha}^{-1}\right]$ & $69.9(14.7)$ & $28.9(2.7)$ & $5.2(0.2)$ & $142.1(14.7)$ & $190.5(8.7)$ & $112.6(10.1)$ & $83.1(8.9)$ \\
\hline N Rate $\left[\mathrm{kg} \mathrm{ha}^{-1}\right]$ & $38.0(34.7)$ & $22.4(18.6)$ & $94.0(13.4)$ & $7.5(4.1)$ & $5.6(1.0)$ & $7.5(7.7)$ & $51.6(33.9)$ \\
\hline P Rate $\left[\mathrm{kg} \mathrm{ha}^{-1}\right]$ & $19.1(17.5)$ & $19.7(10.6)$ & $28.6(10.3)$ & $24.3(5.6)$ & $17.5(2.2)$ & $23.6(8.8)$ & $22.1(12.8)$ \\
\hline $\mathrm{KCl}$ Rate $\left[\mathrm{kg} \mathrm{ha}^{-1}\right]$ & $8.1(7.4)$ & $2.0(6.3)$ & & & & $1.2(3.3)$ & $2.1(5.1)$ \\
\hline S Rate $\left[\mathrm{kg} \mathrm{ha}^{-1}\right]$ & & & $16.4(21.0)$ & & $2.4(1.9)$ & $0.4(1.2)$ & $7.6(20.7)$ \\
\hline \multicolumn{8}{|l|}{ Inoculant Type } \\
\hline Granular or Peat & & & & 11 & 6 & 130 & \\
\hline Liquid & & & & 0 & 0 & 57 & \\
\hline Days to Maturity & $106.0(9.4)$ & $122.9(12.8)$ & $109.3(9.4)$ & $135.5(12.5)$ & $105.0(9.4)$ & $95.6(11.6)$ & $115.5(16.7)$ \\
\hline \multicolumn{8}{|l|}{ Harvest Method } \\
\hline Desiccated & 0 & 0 & 0 & 0 & 0 & 136 & 9 \\
\hline Neither & 3 & 40 & 19 & 11 & 6 & 0 & 212 \\
\hline Swathed & 2 & 42 & 23 & 0 & 0 & 51 & 69 \\
\hline \multicolumn{8}{|l|}{ Drought } \\
\hline No & 5 & 77 & 42 & 7 & 6 & 180 & 265 \\
\hline Yes & 0 & 5 & 0 & 4 & 0 & 7 & 25 \\
\hline \multicolumn{8}{|l|}{ Flood } \\
\hline No & 5 & 81 & 42 & 11 & 6 & 169 & 289 \\
\hline Yes & 0 & 1 & 0 & 0 & 0 & 18 & 1 \\
\hline \multicolumn{8}{|l|}{ Hail } \\
\hline No & 5 & 82 & 42 & 11 & 6 & 182 & 283 \\
\hline Yes & 0 & 0 & 0 & 0 & 0 & 5 & 7 \\
\hline \multicolumn{8}{|l|}{ Copper Sprayed } \\
\hline No & 5 & 82 & 42 & 11 & 6 & 187 & 284 \\
\hline Yes & 0 & 0 & 0 & 0 & 0 & 0 & 6 \\
\hline \multicolumn{8}{|l|}{ Fungicide Sprayed } \\
\hline No & 5 & 59 & 26 & 1 & 6 & 129 & 237 \\
\hline Yes & 0 & 23 & 16 & 10 & 0 & 58 & 53 \\
\hline \multicolumn{8}{|l|}{ Pesticide Sprayed } \\
\hline No & 3 & 67 & 25 & 10 & 6 & 146 & 271 \\
\hline Yes & 2 & 15 & 17 & 1 & 0 & 41 & 19 \\
\hline \multicolumn{8}{|l|}{ Seed Treatment } \\
\hline No & 3 & 80 & 0 & 7 & 6 & 126 & 44 \\
\hline Yes & 2 & 2 & 42 & 4 & 0 & 61 & 246 \\
\hline Average Temp. $\left[{ }^{\circ} \mathrm{C}\right]$ & $16.4(1.2)$ & $15.8(1.1)$ & $16.5(0.9)$ & $15.8(1.4)$ & $15.7(0.4)$ & $15.5(1.0)$ & $16.1(1.2)$ \\
\hline Mean Max. Temp. $\left[{ }^{\circ} \mathrm{C}\right]$ & $35.4(1.6)$ & $34.4(1.9)$ & $36.2(2.8)$ & $35.5(1.8)$ & $37.2(1.4)$ & $33.5(2.3)$ & $34.7(2.2)$ \\
\hline Mean Min. Temp. $\left[{ }^{\circ} \mathrm{C}\right]$ & $-1.7(0.9)$ & $-2.1(2.7)$ & $-1.2(2.6)$ & $-4.0(2.4)$ & $-3.3(1.1)$ & $-2.2(2.8)$ & $-1.9(3.0)$ \\
\hline Mean Rainfall $[\mathrm{mm}]$ & $134.1(121.4)$ & $242.0(87.9)$ & $133.9(87.2)$ & $191.1(74.1)$ & $219.0(89.9)$ & $175.8(85.5)$ & $212.9(88.3)$ \\
\hline \multicolumn{8}{|l|}{ Random Effects } \\
\hline \multicolumn{8}{|l|}{ Frequency } \\
\hline Cultivar & 2 & 3 & 5 & 4 & 1 & 7 & 8 \\
\hline Field & 5 & 30 & 29 & 8 & 6 & 38 & 38 \\
\hline Planting Year & 3 & 23 & 7 & 6 & 2 & 24 & 33 \\
\hline Previous Crop & 3 & 6 & 5 & 3 & 4 & 4 & 7 \\
\hline
\end{tabular}

Note. $\mathrm{n}=$ number of fields; $\mathrm{SD}=$ standard deviation. 
Random intercept models for canaryseed, canola, lentil and wheat crops are presented in Table 3. The highest increase in yield from nutrient supplement at planting was observed with sulphur application for lentil crops; each additional $\mathrm{kg} \mathrm{ha}^{-1}$ above the mean application rate was associated with an increase of $138.5 \mathrm{~kg} \mathrm{ha}^{-1}$ in yield. Interestingly, there is marginal evidence of decreased productivity in lentil crops arising from excess phosphorus fertilization at planting. From the described, a $8.8 \mathrm{~kg} \mathrm{ha}^{-1}$ decrease in yield was observed for each additional $\mathrm{kg}$ $\mathrm{ha}^{-1}$ of phosphorus above the mean application rate. However, phosphorus application for every $\mathrm{kg} \mathrm{ha}^{-1}$ above the mean rate was associated with a $16.2 \mathrm{~kg} \mathrm{ha}^{-1}$ increase in wheat yield. Every additional $\mathrm{kg} \mathrm{ha}^{-1}$ of nitrogen applied above the mean rate was associated with a $19.9 \mathrm{~kg} \mathrm{ha}^{-1}$ yield increase in canola crops.

Table 3. Summary of fixed and random effects at the farming operation from 1986 to 2018

\begin{tabular}{|c|c|c|c|c|}
\hline & \multicolumn{4}{|c|}{ Crop yield in $\mathrm{kg} \mathrm{ha}^{-1}$} \\
\hline & Canaryseed & Canola & Lentil & Wheat \\
\hline \multicolumn{5}{|l|}{ Fixed Effects } \\
\hline \multicolumn{5}{|l|}{$\beta(95 \%$ HPDI $)$} \\
\hline [Intercept] & 1910.6 & -42622.5 & 3390.6 & 7203.5 \\
\hline Seed Rate $\left[\mathrm{kg} \mathrm{ha}^{-1}\right]$ & $22.8(-11.2,51.5)$ & $1111.4(124.1,2047.7)^{*}$ & $-0.8(-6.5,4.7)$ & $2.6(-7.2,11.9)$ \\
\hline $\mathrm{N}$ Rate $\left[\mathrm{kg} \mathrm{ha}^{-1}\right]$ & $-0.1(-7.3,6.3)$ & $19.9(3.2,35.9)^{*}$ & $-4.4(-11.7,3.2)$ & $4.1(-2.5,10.4)$ \\
\hline P Rate $\left[\mathrm{kg} \mathrm{ha}^{-1}\right]$ & $-7.2(-19.7,6.8)$ & $12.3(-1.7,23.8) \dagger$ & $-8.8(-18.1,1.9) \dagger$ & $16.2(0.4,31.0)^{*}$ \\
\hline $\mathrm{KCl}$ Rate $\left[\mathrm{kg} \mathrm{ha}^{-1}\right]$ & $-0.1(-35.4,40.3)$ & & $-8.2(-57.5,38.4)$ & $6.4(-63.7,69.0)$ \\
\hline S Rate $\left[\mathrm{kg} \mathrm{ha}^{-1}\right]$ & & $3.0(-0.9,7.2)$ & $138.5(30.0,237.8)^{*}$ & $-0.4(-5.3,4.4)$ \\
\hline \multicolumn{5}{|l|}{ Inoculant Type } \\
\hline Granular or Peat & & & Ref & \\
\hline Liquid & & & $184.6(-46.7,432.8)$ & \\
\hline Days to Maturity & $-3.9(-17.7,11.2)$ & $43.0(9.4,76.2)^{*}$ & $-3.7(-15.9,7.7)$ & $13.3(4.6,22.2)^{* *}$ \\
\hline \multicolumn{5}{|l|}{ Harvest Method } \\
\hline Neither & Ref & Ref & & Ref \\
\hline Swathed & $-107.2(-310.9,81.6)$ & $499.6(-110.9,1238.1)$ & Ref & $-253.8(-505.8,-5.7)^{*}$ \\
\hline Desiccated & & & $125.4(-116.2,364.1)$ & $645.7(147.8,1167.8)^{*}$ \\
\hline \multicolumn{5}{|l|}{ Copper Sprayed } \\
\hline No & & & & Ref \\
\hline Yes & & & & $202.8(-236.8,624.5)$ \\
\hline \multicolumn{5}{|l|}{ Fungicide Sprayed } \\
\hline No & Ref & Ref & Ref & Ref \\
\hline Yes & $485.5(-152.6,1154.0)$ & $1095.6(335.1,1802.8)^{* *}$ & $-110.4(-343.4,132.5)$ & $21.2(-236.8,624.5)$ \\
\hline \multicolumn{5}{|l|}{ Pesticide Sprayed } \\
\hline No & Ref & Ref & Ref & Ref \\
\hline Yes & $6.1(-570.7,607.8)$ & $-710.3(-1265.8,-171.6)^{*}$ & $12.5(-413.8,383.9)$ & $198.6(-93.6,488.3)$ \\
\hline \multicolumn{5}{|l|}{ Seed Treatment } \\
\hline No & & & Ref & Ref \\
\hline Yes & & & $-364.9(-558.0,-158.3)^{* * *}$ & $-244.9(-463.3,-31.1)^{*}$ \\
\hline Average Temp. $\left[{ }^{\circ} \mathrm{C}\right]$ & $-20.9(-312.0,297.0)$ & $1878.5(1224.0,2637.3)^{* * *}$ & $-67.8(-302.6,167.9)$ & $-410.2(-759.4,-71.7)^{*}$ \\
\hline Rainfall [mm] & $7.8(-9.4,26.2)$ & $171.4(107.8,232.7)^{* * *}$ & $-4.8(-18.6,9.6)$ & $-29.5(-53.2,-5.8)^{*}$ \\
\hline $\begin{array}{l}\text { Interaction: Average Temp. } \\
\text { \& Rainfall }\end{array}$ & $-0.6(-1.9,0.5)$ & $-10.3(-14.2,-6.5)^{* * *}$ & $0.4(-0.6,1.3)$ & $1.9(0.6,3.4)^{* *}$ \\
\hline \multicolumn{5}{|l|}{ Random Effects } \\
\hline \multicolumn{5}{|l|}{ ICC (95\% HPDI) } \\
\hline Cultivar & $0.00(0.00,0.37)$ & & $0.00(0.00,0.05)$ & $0.00(0.00,0.40)$ \\
\hline Field & $0.00(0.00,0.00)$ & & $0.00(0.00,0.00)$ & $0.00(0.00,0.00)$ \\
\hline Planting Year & $0.79(0.36,0.92)$ & & $0.77(0.55,0.89)$ & $0.63(0.23,0.75)$ \\
\hline Previous Crop & $0.00(0.00,0.02)$ & & $0.00(0.00,0.01)$ & $0.09(0.02,0.39)$ \\
\hline
\end{tabular}

Note. HPDI $=$ highest posterior density interval; ICC $=$ intraclass correlation coefficient; MCMC P-value significance level: $\mathrm{P}<0.1(\dagger) ; \mathrm{P}<0.05(*) ; \mathrm{P}<0.01(* *)$ and $\mathrm{P}<0.001(* * *)$. 


\subsection{Seed Treatment, Swathing and Crop Spraying Events}

Seed treatment at planting was used in all canola crops and the majority of wheat crops ( 246 out of 290 fields) (Table 2). Prevalence of seed treatment use was less in lentil crops (61 out of 187 fields), chickpea (4 out of 11 fields) and nonexistent with field pea. A slight majority of canaryseed crops (42 out of 82 fields) were swathed. Most lentil crops (136 out of 187 fields) were desiccated. Fungicide application through crop spraying was made on the majority of chickpea (10 out of 11 fields) crops, some canola (16 out of 42 fields) and lentil (58 out of 187 fields) crops. Pesticide application through crop spraying was less commonly practiced. Canola crops had the highest prevalence of pesticide application (17 out of 42 fields). No spraying of pesticide was applied in the growing of field pea crops. Although not shown (Table 2), record of herbicide use through either granular application or crop spraying was noted on every field planted by the farm operator from 1986 to 2018.

Unexpectedly, the application of seed treatment at planting was associated with a mean decrease in yield for both lentil $\left(364.9 \mathrm{~kg} \mathrm{ha}^{-1}\right)$ and wheat $\left(244.9 \mathrm{~kg} \mathrm{ha}^{-1}\right)$ crops (Table 3). In reference to straight combining, wheat crops that were swathed had a $253.8 \mathrm{~kg} \mathrm{ha}^{-1}$ decrease in yield; those that were desiccated had a $645.7 \mathrm{~kg} \mathrm{ha}^{-1}$ yield increase. Canola crops that were swathed had a mean yield that was $749.7 \mathrm{~kg} \mathrm{ha}^{-1}$ less than canola crops that were straight combined. No difference in yield was observed between canaryseed crops that were swathed or straight combined, or between lentil crops that were swathed or desiccated. Fungicide use was associated with a higher yield in canola crops, at an additional $1095.6 \mathrm{~kg} \mathrm{ha}^{-1}$ on average.

\subsection{Days to Maturity and Climatic Conditions}

Days to maturity varied from a low of 95.6 days on average for lentil crops, to 135.5 days for chickpea (Table 2). For wheat crops, days to maturity was 115.5 days on average. Drought (as noted in field records) occurred infrequently, although coincidently more often when chickpea crops were grown (4 out of 11 fields). Overland flooding (also as noted in field records) was a rare event, with a prevalence most frequent in lentil crops (18 out of 187 fields). Average temperature during the growing season ranged from a low of $15.5^{\circ} \mathrm{C}$ for lentil crops, to a high of $16.5^{\circ} \mathrm{C}$ for canola. Field pea crops had the highest mean maximum temperature during their growing season, at $37.2^{\circ} \mathrm{C}$. Freezing conditions were regularly encountered for each crop at the start of the growing season. Chickpea crops had the lowest mean minimum temperature during the growing season, at $-4.0^{\circ} \mathrm{C}$. Rainfall accumulation over the growing season varied on average from a low of $134.1 \mathrm{~mm}$ for barley crops, to a high of $242.0 \mathrm{~mm}$ for canaryseed crops.

It is of interest to note that an increase in days to maturity above the mean duration was associated with a yield increment for wheat crops and canola crops (Table 3). However, this was not observed for the other crop types. With regard to average temperature, each ${ }^{\circ} \mathrm{C}$ increase was associated with a $410.2 \mathrm{~kg} \mathrm{ha}^{-1}$ decrease in mean yield for wheat crops. With regard to rainfall accumulation for wheat crops, each millimetre increase above the long-term average was associated with a $29.5 \mathrm{~kg} \mathrm{ha}^{-1}$ yield decrease. However, the interaction of each ${ }^{\circ} \mathrm{C}$ and millimetre increase in both temperature and rainfall occurring concurrently was associated with a yield increase of $1.9 \mathrm{~kg} \mathrm{ha}^{-1}$ for wheat crops. The opposite association was observed for canola crops. For canola, each ${ }^{\circ} \mathrm{C}$ increase in average temperature above the long-term mean was associated with a $1878.5 \mathrm{~kg} \mathrm{ha}^{-1}$ increase in mean yield. Each millimetre increase above the long-term average for rainfall accumulation was associated with a $171.4 \mathrm{~kg} \mathrm{ha}^{-1}$ increase in yield.

\subsection{Random Effects}

Table 3 provides information on the proportion of variation in crop yield that was attributable to clustering in a random effect, given by the intraclass correlation coefficient (ICC). Approximately $63 \%$ of the yield variation was attributable to planting year among wheat crops; roughly $9 \%$ of the variation in yield was due to the previous crop grown in field. Among canaryseed and lentil crops, approximately $79 \%$ and $77 \%$ of the variation in yield among was due to planting year, respectively. For all crop types, next to no yield variation was attributable to the cultivar of crop grown, or field.

\section{Discussion and Conclusions}

\subsection{Response to Grain Yield from Average Temperature and Rainfall}

Increases in average rainfall and temperature accumulation during the growing season above the long-term mean were associated with decreased yield in wheat crops over the 33-year period of study. However, the interaction of rainfall accumulation and average temperature was associated with greater wheat yield. This suggests that drought years (increased temperature) and flood years (increased rainfall) occur largely independently and not simultaneously (Hossain et al., 2017), although an increase in both average rainfall and temperature during the same cropping season was beneficial (Robertson, 1974). The opposite relationship was observed in canola crops, 
in that increased average temperature and rainfall accumulation above the long-term mean in the same growing season was associated with decreased yield.

To address why higher rainfall over the long-term average was associated with a yield decrease in wheat crops is worthy of discussion. It is possible that excess rainfall had a flooding effect, or encouraged the growth of pests or plant disease that resulted in decreased wheat yield. The seasonal timing of precipitation events could also have had an effect on wheat yield, with regard to stage of crop development. Long-term rainfall after July at Swift Current, Saskatchewan was negatively associated with wheat yield (Robertson, 1974). A longitudinal study from China found rainfall in excess of $50 \%$ above normal to be associated with decreased wheat yield, with rainfall in growing season being attributable for 70 to $78 \%$ of the variation in wheat yield for some regions (Song et al., 2019). Interestingly, the present study found planting year to be attributable for $63 \%$ of the variation in wheat yield, and higher amounts for other crop types.

\subsection{Farming Practices Detrimental to Grain Yield}

With regard to detrimental crop practices, seed treatment was negatively associated with grain yield in lentil and wheat crops. This was unexpected, but was observed consistently between fields and planting years. A possible explanation is that crops grown with seed treatment were usually seeded earlier (into colder soils) than crops that did not use seed treatment. However, average temperature, rainfall accumulation and length of maturation days were controlled for in the analysis of this study. Research from field plots on the semiarid Canadian prairie has shown some fungicide seed treatments to impede the rate of plant growth, and have no effect on seedling emergence in wheat crops (Fernandez et al., 2009).

Swathing wheat crops as opposed to straight combining in harvest was also associated with decreased yield. This could be due to wheat swaths blowing away in the wind, being consumed by organisms such as rodents and migratory birds, crop compaction from wheel tracks, or grain losses attributable to equipment utilized in swath pick-up. With regard to application of fungicide or pesticide products by in-crop spraying, there is no evidence of their use being associated with a yield difference.

\subsection{Impacts and Challenges}

After adjusting for inputs and farming practices, the vast majority of variation in grain yield was attributable to planting year for canaryseed, lentil and wheat crops on this farming operation. Almost no variation in grain yield was due to crop cultivar or field. This suggests that contextual factors (such as climate) are the major determinants of yield variation between crop years when soil capacity and farming practices are consistent between fields.

In the prairie region of Canada, length of the growing season (frost-free period) is of primary concern when choosing crop types with regards to seeding and harvest dates. For this study, length of frost-free period was highly variable between 1986 to 2018, with a mean of 128 days (Figure 1). The longest frost-free period was 155 days, observed in both 2018 and 1994, respectively. The shortest frost-free period was 78 days in 1992, followed by 100 days in 1993. The abnormally short frost-free periods of 1992 and 1993 were likely due to the eruption of Mount Pinatubo in 1991, which was responsible for global cooling from 1992 to 1993 (Self, Zhao, Holasek, Torres, \& King, 1999). To handle climatic uncertainty, farm operations can hedge through the planting of different crop types in the same planting year (Gan et al., 2003).

What future crops should be the focus of this farm operation and agroecoregion? The answer is not explicit. Diversification requires crops with different lengths of maturation, moisture requirements and frost tolerance. Distribution of rainfall events suggested that crops requiring a longer growing season for maturity (i.e. canaryseed) may also receive higher precipitation from late summer rains. However, sustainability of farming practices should also be of concern. It is likely that there will never be a perfect crop type that is flexible to drought, heavy rainfalls, early frosts, weeds and pests which can be grown with minimal inputs. For perspective, seven different crop types and 30 registered cultivars were grown at this farming operation over a 33-year period (Table 1). Continual improvement in farming on the northern Great Plains requires the uptake of new crops, cultivars and practices that should be made in adaption to climate.

\section{Acknowledgements}

The authors wish to acknowledge and thank Wayne Pittman for the documentation of rainfall and field routines from 1986 to 2018.

\section{References}

Anderson, D. (2010). Vertisolic Soils of the Prairie Region. Prairie Soils \& Crops Journal, 3, 29-36. 
Cruz, A. F., Hamel, C., Yang, C., Matsubara, T., Gan, Y., Singh, A. K., ... Ishii, T. (2012). Phytochemicals to suppress Fusarium head blight in wheat-chickpea rotation. Phytochemistry, 78, 72-80. https://doi.org/ 10.1016/j.phytochem.2012.03.003

Environment Canada. (2019). Daily Data Report (WMO ID: 71142). Retrieved August 13, 2019, from http://climate.weather.gc.ca/climate_data/daily_data_e.html?timeframe $=2 \&$ StationID $=48976$

Fernandez, M. R., Turkington, T. K., \& May, W. E. (2009). Effectiveness of fungicide seed treatments for preventing seed-to-seedling transmission of Fusarium graminearum under controlled-environment conditions. Canadian Journal of Plant Science, 89(4), 811-821. https://doi.org/10.4141/CJPS08132

Gan, Y., Miller, P., Mcconkey, B., \& Zentner, R. (2003). Influence of diverse cropping sequences on durum wheat yield and protein in the semiarid northern Great Plains. Agronomy Journal, 95(2), 245. https://doi.org/10.2134/agronj2003.0245

Gossen, B. D., Peng, G., Wolf, T. M., \& Mcdonald, M. R. (2008). Improving spray retention to enhance the efficacy of foliar-applied disease- and pest-management products in field and row crops. Canadian Journal of Plant Pathology, 30(4), 505-516. https://doi.org/10.1080/07060660809507550

Grant, C. A., \& Flaten, D. N. (2019). 4R Management of Phosphorus Fertilizer in the Northern Great Plains. Journal of Environmental Quality, 48(5), 1356-1369. https://doi.org/10.2134/jeq2019.02.0061

Grant, C. A., Bailey, L. D., Harapiak, J. T., \& Flore, N. A. (2002). Effect of phosphate source, rate and cadmium content and use of Penicillium bilaii on phosphorus, zinc and cadmium concentration in durum wheat grain Journal of the Science of Food and Agriculture, 82(3), 301-308. https://doi.org/10.1002/jsfa.1034

Hadfield, J. D. (2010). MCMC Methods for Multi-Response Generalized Linear Mixed Models: The MCMCglmm R Package. Journal of Statistical Software, 33(2), 1-22. https://doi.org/10.18637/jss.v033.i02

Hopkins, J. W. (1935). Weather and wheat yield in western Canada: Influence of rainfall and temperature during the growing season on plot yields. Canadian Journal of Research, 12(3), 306-334. https://doi.org/ $10.1139 /$ cjr35-027

Hossain, Z., Wang, X., Hamel, C., Knight, J., Morrison, M., \& Gan, Y. (2017). Biological nitrogen fixation by pulse crops on semiarid Canadian prairies. Canadian Journal of Plant Science, 97(1), 119-131. https://doi.org/10.1139/CJPS-2016-0185

Johnson, R. A., Mandel, J. S., Gibson, R. W., Mandel, J. H., Bender, A. P., Gunderson, P. D., \& Renier, C. M. (1993). Data on prior pesticide use collected from self- and proxy respondents. Epidemiology (Cambridge, Mass.), 4(2), 157-164. https://doi.org/10.1097/00001648-199303000-00012

Lafond, G. P. (1994). Effects of row spacing, seeding rate and nitrogen on yield of barley and wheat under zero-till management. Canadian Journal of Plant Science, 74(4), 703-711. https://doi.org/10.4141/ cjps94-127

May, W., Lafond, G. P., Gan, Y., Hucl, P., Holzapfel, C., Johnston, A., \& Stevenson, C. (2012). Yield variability in Phalaris canariensis L. due to seeding date, seeding rate and nitrogen fertilizer. Canadian Journal of Plant Science, 92(4), 651-669. https://doi.org/10.4141/cjps2011-126

McCallum, B. D., \& DePauw, R. M. (2008). review of wheat cultivars grown in the Canadian prairies. Canadian Journal of Plant Science, 88(4), 649-677. https://doi.org/10.4141/CJPS07159

McDonald, J. L., Stott, I., Townley, S., Hodgson, D. J., \& Griffith, A. (2016). Transients drive the demographic dynamics of plant populations in variable environments. Journal of Ecology, 104(2), 306-314. https://doi.org/10.1111/1365-2745.12528

Perilli, P., Mitchell, L. G., Grant, C. A., \& Pisante, M. (2010). Cadmium concentration in durum wheat grain (Triticum turgidum) as influenced by nitrogen rate, seeding date and soil type. Journal of the Science of Food and Agriculture, 90(5), 813-822. https://doi.org/10.1002/jsfa.3889

R Core Team. (2018). R: A Language and Environment for Statistical Computing. Retrieved from http://www.r-project.org

Robertson, G. W. (1974). Wheat Yields For 50 Years at Swift Current, Saskatchewan In Relation to Weather. Canadian Journal of Plant Science, 54(4), 625-650. https://doi.org/10.4141/cjps74-112

Self, S., Zhao, J. H., Holasek, R. E., Torres, R. C., \& King, A. (1999). The Atmospheric Impact of the 1991 Mount Pinatubo Eruption. Retrieved February 4, 2020, from https://pubs.usgs.gov/pinatubo/self 
Song, Y., Linderholm, H. W., Wang, C., Tian, J., Huo, Z., Gao, P., ... Guo, A. (2019). The influence of excess precipitation on winter wheat under climate change in China from 1961 to 2017. Science of the Total Environment, 690, 189-196. https://doi.org/10.1016/j.scitotenv.2019.06.367

Waite, D. T., Cessna, A. J., Grover, R., Kerr, L. A., \& Snihura, A. D. (2004). Environmental Concentrations of Agricultural Herbicides in Saskatchewan, Canada: Bromoxynil, Dicamba, Diclofop, MCPA, and Trifluralin. Journal of Environmental Quality, 33(5), 1616-1628. https://doi.org/10.2134/jeq2004.1616

Zhang, T., Johnson, E. N., Mueller, T. C., \& Willenborg, C. J. (2017). Early Application of Harvest Aid Herbicides Adversely Impacts Lentil. Agronomy Journal, 109(1), 239. https://doi.org/10.2134/agronj2016. 07.0419

\section{Copyrights}

Copyright for this article is retained by the author(s), with first publication rights granted to the journal.

This is an open-access article distributed under the terms and conditions of the Creative Commons Attribution license (http://creativecommons.org/licenses/by/4.0/). 